Z. klin. Chem. u. klin. Biochem.

7. Jg., S. $624-626$, November 1969

\title{
A New Medium for the Aldohexose-o-Toluidine Reaction: Direct Microdetermination of Blood Glucose
}

\author{
By J. Bierens de HaAN and M. Roth \\ Laboratoire central, Hôpital cantonal, Genève, Suisse
}

(Eingegangen am 25. Juli 1969)

\begin{abstract}
A solution of glycollic acid in a mixture of benzyl alcohol and hexamethylphosphoric triamide is proposed to replace acetic acid in the glucose determination with o-toluidine as applied directly to blood plasma.

The new reagent is non-volatile, odourless, colourless, of low viscosity and stable for weeks at room temperature. It does not precipitate serum proteins.

The method is particularly suited to discrete mechanization. Its sensitivity and overall reliability are higher than that of the acetic-acid method.

Zur direkten Glucose-Bestimmung im Blutplasma mit o-Toluidin wird eine neue Reagenzzusammensetzung vorgeschlagen, in welcher die Essigsäure durch eine Lösung von Glykolsäure in einem Gemisch von Benzylalkohol und Hexamethylphosphortriamid ersetzt wird. Das Reagenz ist farblos und geruchlos; es ist nicht flüchtig, besitzt eine geringe Viskosität und ist über mehrere Wochen bei Raumtemperatur haltbar. Es fällt die Proteine nicht aus.

Die Methode eignet sich vorzüglich zur diskreten Mechanisierung. Empfindlichkeit und allgemeine Zuverlässigkeit sind besser als die der Methode mit Essigsäure.
\end{abstract}

Because of their lack of specificity, methods that rely upon the reducing power of glucose are now almost completely disregarded, but, in turn, the reliability of the widely adopted glucose-oxidase methods is being more and more questioned by the analyst. This is justified, at least, for the glucose-oxidase "equilibrium" methods with non-specific, colorimetric determination of hydrogen peroxide (with or without peroxidase). The error is generally negative, due to the very high reactivity of hydrogen peroxide which tends to lower the overall recovery of the method. To minimize these errors, and despite the fact that none of the reagents used is really incompatible with dissolved proteins, most of the glucose-oxidase methods imply a tedious and hardly mechanizable deproteinization step. So far as glucose-oxidase methods are concerned, the kinetic approach looks much more promising.

The most accurate and specific technique presently available (i. e. the reference method for blood glucose determination) might well be the newly developed hexokinase method, but the high cost and, as above, the difficulties encountered with the handling of labile enzyme reagents has prevented it so far from being widely accepted as a routine procedure.

Six years experience with the glucose-o-toluidine reaction in acetic acid medium enabled us to perform, until April 1969, eighty thousand determinations a year with entire satisfaction. The method is aldohexose-specific, sensitive, precise and accurate enough for the requirement of the clinical laboratory. Furthermore it is very fast and simple to perform. The manual technique is ideally suited to the handling of emergencies but, due to the use of acetic acid much less convenient for the hundreds of determinations performed daily in the routine laboratory. Its automated modification, first described by ZENDER (1) and used in our laboratory with several minor improvements for two thirds of the total work load, brings the usual advantages of closed circuit operation, i. e. the corrosive effect and inconvenience of acetic acid vapors are minimized. Except for this, the use of the Technicon Autoanalyzer would rather be a drawback because of its slowness, the high sample volume required $(150-200 \mu l)$ and the drift problems that are always associated with continuousflow techniques.

The recent and very stimulating work of HärTEL and LANG (2) is the first successful attempt to replace acetic acid by an odorless, non-volatile, low-viscosity reaction medium. Unfortunately, the mixture proposed by these authors lacks a useful property of acetic acid, that is its ability to keep plasma proteins in solution. Further, the stability of the coloured product after cooling is not quite sufficient for serial analyses and this obliges the technician to re-standardize his instrument every two or three minutes.

The composition of the reagent proposed below is a compromise resulting from empirical research work based upon the findings of HÄrTRL and LANG. Many different solvents/acid/water/o-toluidine combinations have been tested. The reagent composition, the heating temperature, the heating time and the plasma to reagent volume ratio have been studied with special consideration of their influence upon

- the reagent stability

- the compatibility with dissolved proteins (after heating)

- the kinetics of colour development (ascending portion of heating curve) 


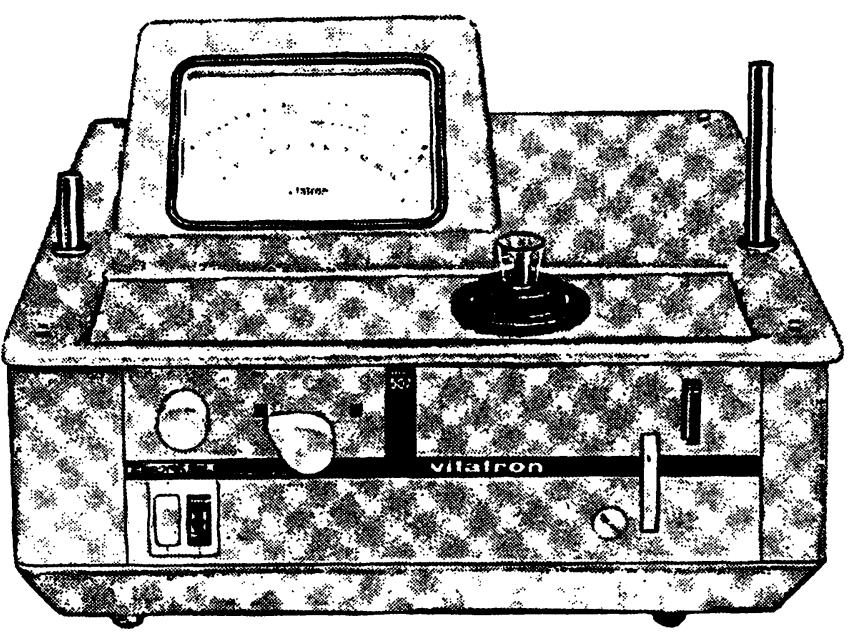

Es hat die Stabilität und Linearität eines

Doppel-Strahl Monochromator-Gerätes, kostet aber weniger als die Hälfte.

Wir können Ihnen hier nicht all seine Vorzüge beschreiben. Aber wenn Sie in Ihrem Labor ein wenig Platz übrig haben (nur $32 \mathrm{~cm} \times 32 \mathrm{~cm}$ ),

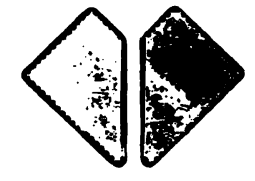

Wir sind sicher:

Das VITATRON UC 200 PRÄZISIONS-COLORIMETER ist eines der stabilsten Ein-Strahl-Photometer der Welt.

- Zweikanal-D̄oppelstrahlgerät

- Gleichzeitige Analyse von 2 Elementen oder

- Analysen mit internem Standard

- Konzentrationen direkt in jeder gewünschten Einheit digital ablesbar

- Kanal A mit Gitter:Monochromator und Revolverkopf für 6 Lampen

- Kanal B vorgesehen für Interferenzfilter

- Einfache Umschaltung auf Emission

- Automatische Zündung der Flamme

- Sicherheitsvorrichtungen für Brenner und Vérnebelungskammer

- Eingebauter Integrator

- Automatische Nullpunkt- und Eichkorrektur

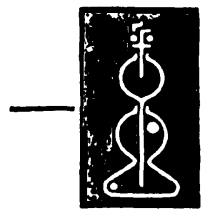




\title{
Blut-Gerinnungs-Substrat-Plasmen und Réagenzien
}

\author{
zur spezifischen Ein-Schritt-Bestimmung von Blutfaktoren
}

Jedes Substrat-Plasma enthält ausreichende Mengen der übrigen für die Bestimmung erforderlichen Gerinnungsfakłoren. Alle unten angebotenen Substrat-Plasmen stammen vom Rind und enthalten Fibrinogen und Faktor $V$ im Überschuß.

\author{
Fakłor II - freies Plasma \\ Bestell-Nr. B 2 D
}

Zur Bestimmung von Faktor II mit Gehirn-Thromboplastin nach Koller, F. U. Mitarb. Acta haemat. 6, 1 (1951)

Menge

$6 \times 2 \mathrm{ml}$ Ampullen

$24 \times 2 \mathrm{ml}$ Ampullen max. mögl. Bestimmungen

120

480
Preis

$\$ 9,00$

$\$ 30,00$

Faktor II und VII - freies Plasma Bestell-Nr. B 2 - 7 D

Zur Bestimmung von Faktor II mit Russell's Schlangengift in Cephalin (nicht für Bestimmungen mit Gehirn-Thromboplastin zu verwenden) nach Hjort, P. U. Mitarb. J. Laborat. Clin. Med. S. Louis 46,89 (1955)

Menge

max. mögl. Bestimmungen

Preis

$6 \times 2 \mathrm{ml}$ Ampullen

$24 \times 2 \mathrm{ml}$ Ampullen

120

480

$\$ 9,00$ $\$ 30,00$

Faktor VII und $X$ - freies Plasma Bestell-Nr. B 7 - 10 D

Zur Bestimmung von Faktor $X$ mit Russell's Schlangengift und des „VII bis X-Komplexes" (nicht spezifisch für Faktor VII) nach Bachmann, F. U. Mitarb. Thrombos. Diath. Haemorrh. 2, 24 (1958)

Menge

$6 \times 2 \mathrm{ml}$ Ampullen max. mögl. Bestimmungen

$24 \times 2 \mathrm{ml}$ Ampullen

480

Preis

$\$ 9,00$ $\$ 30,00$

Faktor II, VII und $X$ - freies Plasma

Bestell-Nr. B 2, 7, 10 D

Zur kombinierten Bestimmung der Aktivität der Faktoren II, VII und X nach Toohey, M., J. Clin. Path. 11, 56 (1958)

Menge

$6 \times 2 \mathrm{ml}$ Ampullen

max. mögl. Bestimmungen

Preis

$24 \times 2 \mathrm{ml}$ Ampullen

120

$\$ 6,00$ $\$ 15,00$

\section{Russell's Schlangengift in Cephalin} Bestell-Nr. RVC - L

Zur Bestimmung von Fakłor II mit Substratplasma (B̈estell-Nr. B 2-7 D) und Faktor $X$ mit Substratplasma (Bestell-Nr. B 7 - 10 D)

\section{Menge}

$6 \times 3 \mathrm{ml}$ Ampullen

$12 \times 3 \mathrm{ml}$ Ampullen

max. mögl. Bestimmungen

Preis

$48 \times 3 \mathrm{ml}$ Ampullen

$$
\begin{aligned}
& 180 \\
& 360
\end{aligned}
$$

360
1440

$\$ 9,00$

$\$ 16,00$

$\$ 50,00$

\section{Cephalin aus Kaninchengehirn \\ Bestell-Nr. RBC}

Als Zusatz zur Thrombocytensuspenșion für die Bestimmung der Partiellen Thromboplastinzeit, der Thromboplastinbildungszeit und anderer Phospholipid-abhängiger Blutgerinnungstests nach Bell, W. N. und Alton, H. C., Nature (London) 174, 880 (1954)

Menge

1 Ampulle

3 Ampullen

max. mögl. Bestimmungen

1000 (Partielle

3000

Thromboplastinzeit)

Preis $\$ 15,00$ $\$ 35,00$

Fordern Sie bitte unseren neuesten Katalog an, der weitere Blutgerinnungs-Produkte enthält. Kunden-Muster von Reagenzien für Forschungszwecke auf Anfrage.

Sigma-Reagenzien sind in der ganzen Welt durch den Fachhandel oder direkt aus St. Louis beziehbar.

Telegramme: SIGMACHEM, St. Louis, Missouri

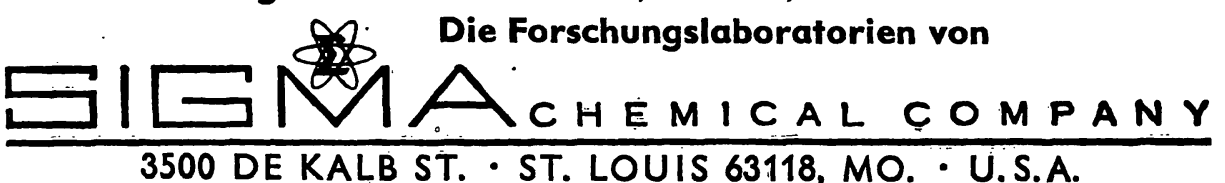

3500 DE KALB ST. - ST. LOUIS 63118, MO. -U.S.A.

MANUFACTURERS OF THE, FINEST BIOCHEMICALS AVAILABLE 
- the kinetics of colour discharge (descending portion of heating curve and stability of the coloured product after cooling)

- the sensitivity of colour yield

- the linearity of absorbance vs. concentration (BEER's law).

\section{Method}

\section{Reagent (LC-4.69)}

Mix, in the order indicated, and ensure that the resulting mixture is homogeneous after each addition:

\section{thiourca}

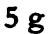

distilled water

$200 \mathrm{ml}$

glycollic acid

$200 \mathrm{~g}$

hexamethylphosphoric triamide $200 \mathrm{ml}$

benzyl alcohol $380 \mathrm{~m}$

o-toluidine $\quad 100 \mathrm{ml}$

(The thiourea and benzyl alcohol are Merck p. a. grade; crystalline glycollic acid may be obtained from Koch-Light Inc.; hexamethylphosphoric triamide and o-toluidine p. a. grade may be obtained from Schuchardt; the latter product must be freshly redistilled and colourless; the resulting mixture shows low viscosity and is stable at least for several weeks.)

\section{Procedure}

Add $10 \mu l$ plasma and $2 \mathrm{ml}$ reagent to a test tube (approx. $10 \mathrm{ml}$ capacity), mix well, heat in a boiling water bath for ten minutes, cool in running tap water, transfer to photometer cuvette and read absorbance at $650 \pm 10 \mathrm{~nm}$.

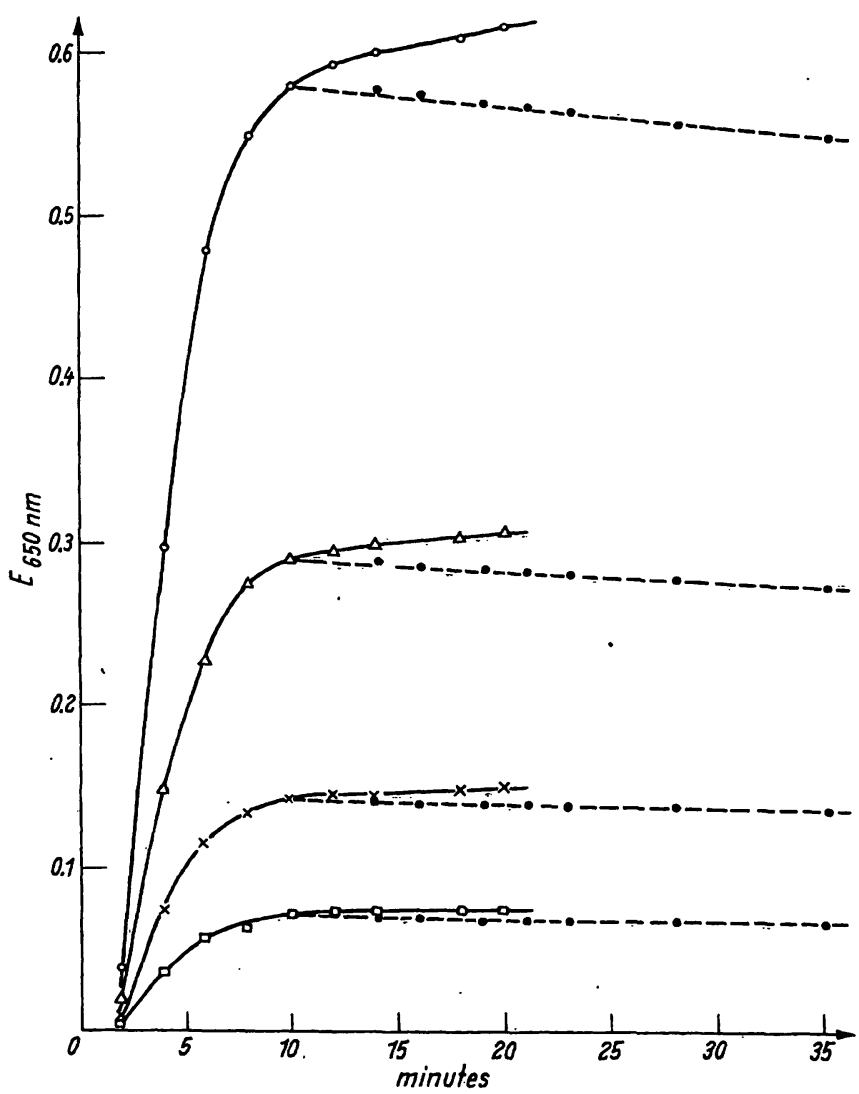

Fig. 1

Heating curves $\left(98^{\circ}\right.$, solid lines) and stability after cooling $\left(12^{\circ}\right.$, dashed lines) for the dye from glucose $10 \mu l$ sample $+2 \mathrm{ml}$ reagent $L C-4.69$ $0=4 \mathrm{~g} / \mathrm{l} \quad \Delta=2 \mathrm{~g} / \mathrm{l} \quad x=1 \mathrm{~g} / \mathrm{l} \quad \square=0.5 \mathrm{~g} / \mathrm{l}$

\section{Remarks}

The heating time is not very critical as shown on figure 1: the heating curve becomes almost horizontal after $10 \mathrm{~min}$ at $97-98^{\circ} \mathrm{C}$. The absorbance loss, after

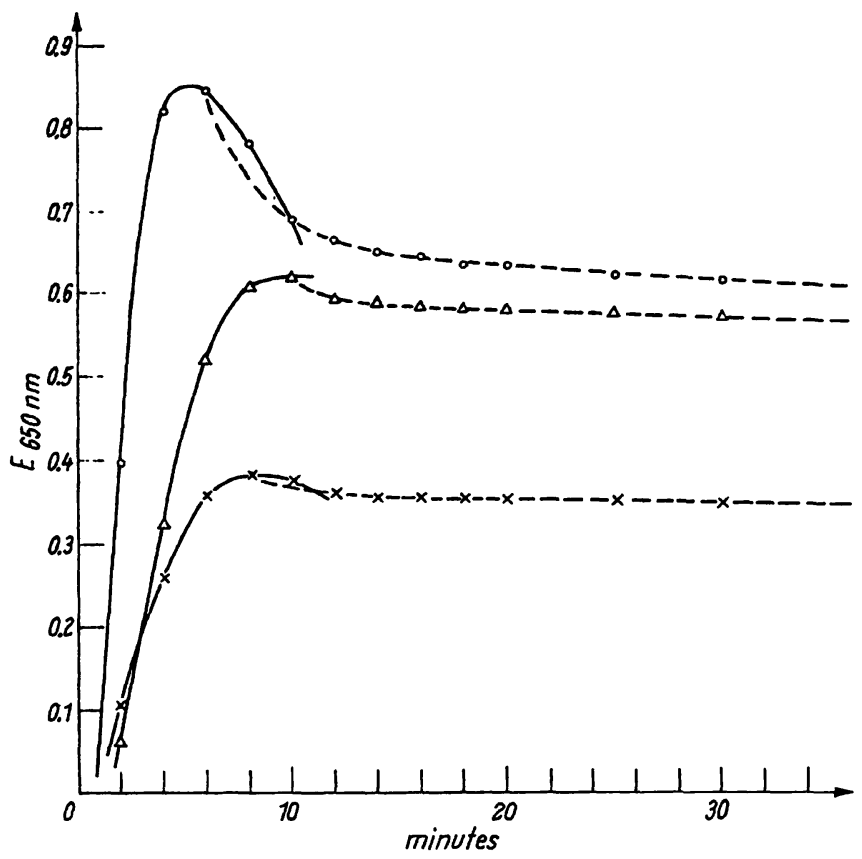

Fig. 2

Comparison between three o-toluidine methods for glucose: heating curves $\left(98^{\circ}\right.$, solid lines) and stability after cooling (120, dashed lines) $40 \mu \mathrm{g}$ glucose $+2 \mathrm{ml}$ reagent:

$x=0$-toluidine-acetic acid (sol. Merck 8313), $8 \mathrm{~min}$

$\Delta=$ reagent $L C-4.69,10 \mathrm{~min}$

0 = reagent after HÄRTEL and LANG (2), $6 \mathrm{~min}$

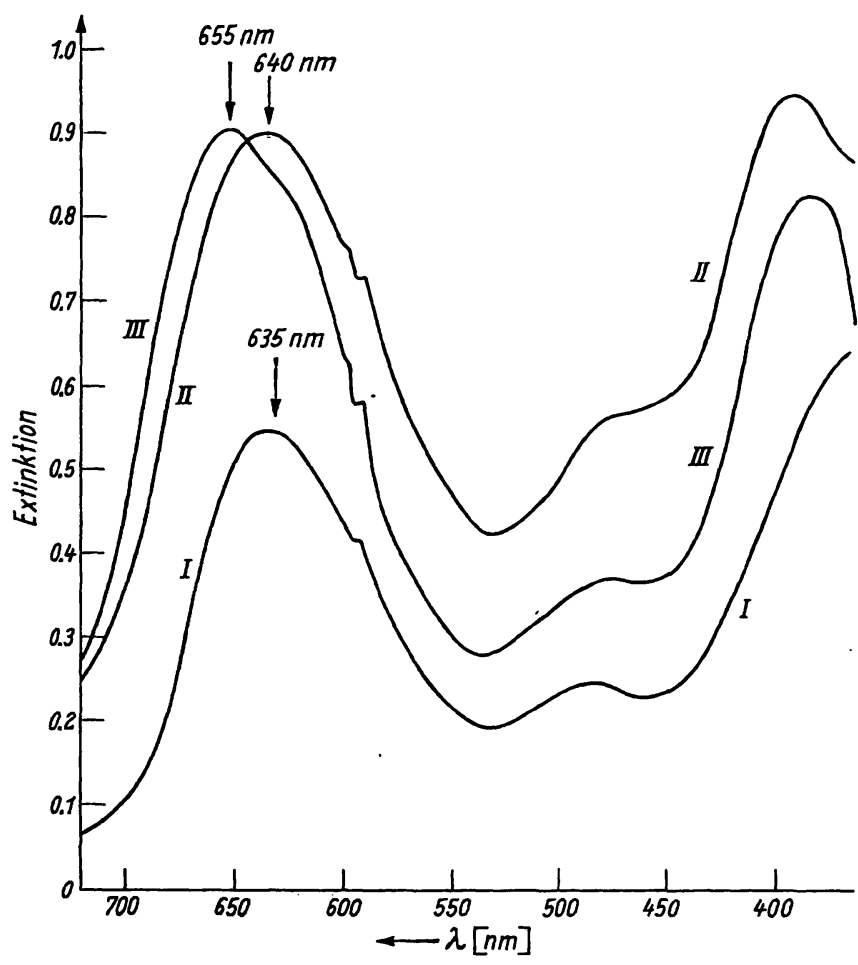

Fig. 3

Comparison between three $o$-toluidine methods for glucose: absorption spectra of final mixture (heating time $\left.10 \mathrm{~min}, 98^{\circ}\right) 40 \mu \mathrm{g}$ glucose $+2 \mu \mathrm{l}$ reagent:

$I=0$-toluidine-acetic acid (sol. Merck 8313)

II = reagent after HÄRTEL and LANG (2)

Z. klin. Chem. u. klin. Biochem. / 7. Jahrg. 1969/ Heft 6 
cooling, is less than $0.25 \%$ per min, allowing 6 to 8 min intervals between the readings of standard and unknown. BEER's law is followed up to $6 \mathrm{~g} / \mathrm{l}$ plasma glucose. Haemoglobin or bilirubin do not interfere. Figure 2 and 3 show a comparison between the three o-toluidine methods, i. e.:

1. direct method after Michod and FreI (3)

2. method of Ḧ̈RTEL and LANG without acetic acid, with deproteinization

3. direct method proposed in this paper.

\section{Applications}

The method is used presently in our laboratory, on a large scale, with the aid of an auto-diluter Hook \& Tucker MK II (6 seconds cycle), a thermostated water bath of 35 liters and 0.2 sq meter area. After cooling and pouring into disposable plastic cuvettes, the readings are performed with a mechanized filter photometer LKB ultrolab 7400 which reads, computes and prints 1500 analyses an hour. The overall yield of a single technician easily exceeds a hundred determinations an hour (centrifugation excluded).

\section{References}

1. Zender, R., Clin. chim. Acta (Amsterdam) 11, 88 (1965). - 2. Härtex, A., R. Helger and H. LaNg, this journal 7, 14 (1969). 3. MrсноD, J., and J. Frer, Med. Laborat. 18, 25 (1965).

Dr. J. Bierens de Haan

PD Dr. M. Roth

Hôpital cantonal

CH-1211 Genève 4 